\title{
Work as the primary 'duty' of the responsible citizen: a critique of this work-centric approach
}

\author{
Ruth Patrick* \\ University of Leeds
}

\begin{abstract}
Focusing on the British case, this paper provides an analysis of the ways in which the responsibility to work is today characterised as the primary duty of the 'good' citizen. Following an exploration of how paid work is conceptualised, and the citizenship framework on which this conceptualisation rests, a brief review of relevant policy measures in this domain highlights continuity and change between the approaches of New Labour and the Coalition. This paper then explores the rhetorical devices and binary distinctions employed to uphold and sustain distinctions between the behaviour of workers and those reliant on welfare for all, or most, of their income. The contemporary valorisation of work is critiqued, with emphasis placed on the exclusionary citizenship consequences for those who do not engage in the formal labour market. A work-centric approach adopts a narrow and overly-restrictive understanding of both work and dependency, omitting analyses of inequalities amongst the working population, as well as issues of the deservingness and responsibilities of the rich. Inevitably, simplistic and unsustainable binary distinctions between 'work' and 'dependency' only serve to further exclude and demoralise those already on the margins of social exclusion.
\end{abstract}

Keywords: work, dependency, welfare, citizenship, responsibility.

\section{Introduction}

Social policy has long been interested in politicians' efforts to change the behaviour of disruptive or problematic populations and welfare has always been conceptualised as one policy mechanism for engineering or promoting desired behavioural change (Deacon, 2002). Recent trends in welfare-to-work policy have seen the economically inactive and unemployed constructed as 'problematic' populations who need tough interventions if their behaviour is to be changed such that they become working and productive members of mainstream society. An emphasis on the necessity of promoting formal paid labour, and a reliance on the policy tools of activation and welfare conditionality, is today notable across the OECD region and extends to the Nordic countries whose welfare states traditionally rested on a more decommodified model of labour (Gilbert and Besharov, 2011). 
In the UK, the 2011 Welfare Reform Bill promises tough new measures to ensure that work always pays and to end the 'option' of welfare dependency, with a ratcheting up of sanctions and new conditions for those who do not comply with the welfare-towork regime (Department for Work and Pensions, 2010). While the Coalition governs against a particular social and economic backdrop, shaped by a tough economic climate and the aftermath of England's worst riots for over two decades, it is notable how far their agenda on welfare reform appears to mimic and replicate that of New Labour. As the Coalition approaches its two year anniversary in Government, it is timely to explore the valorisation of work in which much of the welfare reform policies and associated discourses are rooted.

\section{Mapping the theoretical terrain - social citizenship and the responsibility to work}

Ideas of social citizenship are central to thinking about questions of inclusion and exclusion - citizenship is valued precisely because it denotes membership of a community and there will always be some who are excluded from that community (Lister, 2003). How citizenship is framed and understood determines who is included and excluded from the citizenship community. The two central models of citizenship liberal and civic republican - both put marked emphasis on duty and responsibilities with the former conceptualising rights and responsibilities bound together, while the latter puts more stress on responsibilities that can arise regardless of government intervention (Dwyer, 2010). Communitarian thinking is best understood as a particular, often conservative, strand of the broader civic republican tradition.

Commentators on the New Labour regime consistently observed the single-minded focus on paid work as the primary social obligation which citizens should be expected to fulfil (cf. Dean, 1999; Prideaux, 2005; Lister, 2001), an observation which can be validly extended to the Coalition. Today, we find evidence of both liberal contractualist and communitarian arguments operationalised by parties of left and right to defend and uphold this emphasis on the duty to work. In the most common liberal contractualist articulation, the right to welfare benefits is balanced and offset by the responsibility actively to look for and take steps to return to work. The language of welfare contractualism and 'rights and responsibilities' has become commonplace in British politics, with first New Labour and then the Conservatives clamouring to usher in a new 'welfare contract' that properly rewards work and makes the right to benefit strictly conditional on claimants participating in back-to-work activities (cf. Department for Social Security, 1998; Conservatives, 2010). Under a more communitarian sentiment, we sometimes see a duty to work characterised as the responsibility of all citizens - the most fundamental duty of the 'good' citizen regardless of what support he or she may be receiving from government (Deacon, 2002). Recourse to communitarian arguments tends to exhibit a more explicit moralising undertone, with work valorised as both the duty and reward of the good citizen (Levitas, 2005).

There has long been a strong emphasis on the responsibility to work in citizenship theorising and public policy, with T H Marshall accompanying his articulation of the rights of social citizenship with a call for individuals to put their 'heart into one's job' (1949: 46). As far back as 1572, legislation charged the overseers of the poor with sending vagrants to work (Piven, 1972), while the creation and reinforcing of divisions between the deserving and undeserving poor stretches back to the 1834 Poor Law Amendment Act and beyond. What is distinctive about the contemporary climate, however, is both the frequency with which politicians highlight work as the primary duty of the responsible citizen, as well as the mainstreaming of this duty, which now extends 
ever further to include almost the entire working age population. Traditionally, certain groups were excluded from the responsibility to participate in paid work; most notably mothers, disabled people and the elderly. While the elderly largely retain their protected status, as part of the shift from a welfare to an active society (Walters, 1997), and from a male breadwinner to a two adult worker household model, benefit claiming mothers and many disabled people are now expected to attempt to join the formal labour market. Welfare reforms since the mid-1990s have sought to encourage lone parents into paid work, while many disabled people are now finding their eligibility for unconditional benefits reassessed as they are migrated from Incapacity Benefit (IB) onto Employment and Support Allowance (ESA) (Deacon and Patrick, 2011).

Characterising work as the hallmark of the responsible citizen, and reducing the category of those not expected to work to a residual group of the most 'deserving' disabled people, lone parents with very young children and full-time carers, has inevitable exclusionary consequences for those who cannot or who choose not to work, perhaps due to prioritising other commitments (Lister, 2003). Even those who are not expected to work will experience the valorisation of work as an exclusionary discourse that operates to celebrate hard working behaviours while implicitly undermining other forms of contribution such as caring, parenting, volunteering and service user engagement - activities in which many 'non-workers' are often involved.

\section{Work is the best form of welfare? The transformative potential of paid work}

While denoting work as the responsibility of the dutiful citizen, politicians also put marked emphasis on the transformative potential of paid employment. Politicians repeatedly proclaim the scope for work to deliver rewards which extend beyond pecuniary remuneration to improved physical and mental health, rising self-esteem, better family life and increased opportunities for children (Department for Social Security, 1998; Department for Work and Pensions, 2008; 2010). 'Work is the best form of welfare' (Department for Work and Pensions, 2008: 38) is a mantra similarly popular with both New Labour and the Coalition, and helping the nation back to work is judged by the Coalition to be central to fixing 'Broken Britain'.

In governmental discourses, work is seen as an unproblematic good, with politicians almost completely silent on questions regarding the type of work needed to deliver these transformative rewards, while also tending to neglect the enduring reality of inwork poverty. This is problematic for two central reasons. Firstly, over half of workingage adults in poverty live in households where at least one person is working - a pertinent challenge to the 'work is the best form of welfare' mantra (Newman, 2011). As numerous academic studies have shown, paid work is indeed the surest route out of poverty but it is by no means a guaranteed one (Crisp et al., 2009). Secondly, the assumption that work will improve physical and mental health and broader wellbeing depends in large part on the type of work in which individuals are engaged, a reality which politicians continue to ignore, despite government-commissioned research highlighting this finding. Studies demonstrate that low paid, menial and insecure work does not deliver the much hyped rewards and, conversely, insecure work for poverty wages can actually harm family life and individual wellbeing (Wadell and Burton, 2006; Overell, 2011). In Britain today, there are some two million vulnerable workers engaged in work that is insecure and badly paid (TUC, 2008, cited in Crisp et al., 2009). Many of these individuals are trapped in a cycle of 'poor work' and worklessness that sees them transitioning between benefits and unemployment, often unable to move up the employment ladder (Crisp et al., 2009). A political discourse that simplistically promotes all work, generalising about rewards supposedly available to all those in 
employment, neglects the reality for badly paid workers who are often simultaneously struggling to remain in employment and to cope with life below the poverty line.

\section{From welfare to work: Continuity and change from New Labour to the Coalition}

While the Coalition argues that it is developing a distinctive welfare reform agenda, describing itself as the Government to finally get tough on welfare dependency and non-work (cf. Duncan Smith, 2010; Cameron, 2011b), there are in fact marked similarities between the Coalition's approach and its New Labour predecessors. Indeed, the Coalition seems to be simply extending New Labour's reliance on welfare conditionality and sanctions with their Welfare Reform Bill legislating for the ultimate sanction: three years without benefits for those who three times fail to comply with the government's welfare-to-work regime (Department for Work and Pensions, 2010). Alongside this, the Coalition is continuing New Labour's disability benefit reforms by migrating all existing Incapacity Benefit claimants onto Employment and Support Allowance. The Coalition has also launched its Work Programme to replace the previous plethora of back-to-work schemes which included New Labour's totemic New Deals. In another sign of continuity between New Labour and the Coalition, the Work Programme shows marked similarities with the Flexible New Deal, an integrated programme of back-to-work support piloted by Brown's Government in his final months as Prime Minister (Deacon and Patrick, 2011).

Employability programmes such as New Labour's New Deals and the Coalition's Work Programme place emphasis on the individual barriers facing those out of work, focusing on the supply-side of the labour market, and seeming to implicitly suggest that those out of work are ultimately responsible for their own unemployment (Newman, 2011). Policy energies and rhetorical discourses are centred on how best to activate the economically inactive, with the corrective lens firmly focused on the steps individuals must take to make themselves more employable. A work-first approach predominates that utilises tough conditions and sanctions to activate those not engaged in paid employment. This policy focus subtly neglects the structural factors which may make these efforts more problematic, including the state of the labour market, the realities of low-paid, insecure employment and continued issues around the availability of affordable childcare (Deacon and Patrick, 2011). The government's analysis of the welfare-to-work 'problem' also assumes that a culture of worklessness exists in many of Britain's most deprived communities. However, there is little evidence that benefit claimants and Britain's poorest actually lack a work ethic, with research often uncovering determined aspirations to work, aspirations which are most often frustrated by demand-side rather than supply-side labour market barriers (Crisp et al., 2009; Newman, 2011).

Given the extent of agreement on the direction of welfare reform, it is today possible to sketch out a new welfare settlement which sees all three parties in broad agreement on the tools and objectives of welfare-to-work policy (Deacon and Patrick, 2011). All three parties promote work as the duty of the responsible citizen, characterising work as the best form of welfare for the great majority of the working-age population. There is an explicit moralising common to policy statements and speeches from the Liberal Democrats, New Labour and the Conservatives, with politicians from all parties asserting the innate goodness of work and contrasting problem of welfare dependency. Welfare benefits are construed as operating as barriers to work, with parties competing to be seen as having the greatest capacity to finally tackle perceived 'entrenched welfare dependency'. There is widespread agreement that welfare conditionality is the policy tool for activating benefit claimants, and politicians of all colours are comfortable employing sanctions to ensure that responsible, working behaviour is encouraged while 
those not keeping their side of the welfare bargain face tough consequences (Dwyer, 2010; Deacon and Patrick, 2011; Wright, 2009).

Although it is possible to describe a consensual character to the political parties positioning on welfare-to-work, there are some early signs of divergence when contrasting the approach taken by the Coalition with that of New Labour. The Coalition has embarked on an ambitious programme of welfare residualisation which will see the total benefits bill fall by $£ 18$ bn by 2014-15 (Toynbee, 2011). While New Labour would certainly have also cut welfare expenditure had it retained power in 2010 , there are unanswered questions regarding whether it would have been willing to reduce benefits quite so substantially. What is more, soon after entering office the Coalition ended the Future Jobs Fund - a programme of job creation which New Labour had introduced to try to increase youth employment. While New Labour generally placed more stress on the supply-side of the labour market throughout its time in office, the Future Jobs Fund represented an intervention on the demand-side during a time of economic recession and the Coalition's apparent resistance to support any job creation policies may mark out some ideological disparities between the two administrations. Furthermore, while both administrations place marked emphasis on the importance of making work pay early signs suggest the Coalition sees reducing benefit payments as the best way to achieve this whereas New Labour focused more on increasing the rewards of work via tax credits and financial assistance with the costs of childcare. While these areas of difference are important, what is most notable is the broader welfare settlement that sees all three main parties in agreement about both the supposed problem of welfare dependency and the posited solution of tough conditions and sanctions to activate benefit claimants.

\section{Sustaining and reinforcing dualistic and exclusionary divisions between responsible workers and irresponsible benefit claimants}

Before problematising the Government's work-centric focus, it is important to pause and explore how mainstream political discourses reinforce and sustain divisions between workers and non-workers in ways that exclude and stigmatise those not behaving as the Government would like. Making distinctions between deserving and undeserving populations has a long history (Warren, 2005); one that has always been particularly focused on judging and categorising the behaviour of the poorest in society who seek assistance from the state. Today, the Government appears to be capitalising on and reimagining these divisions in order to defend and justify its policy approach. Like New Labour, the Coalition's distinctions between the deserving and undeserving operate around a work - non-work axis. Those engaging in paid work are characterised as independent, responsible citizens while those out-of-work are by contrast dependent, irresponsible and arguably even conceptualised as second-class citizens, given their failure to fulfil the most central of citizenship obligations. In a typical narrative of this type, Duncan Smith used his speech at the 2010 Conservative Party Conference to valorise the working majority, contrasting their responsible, honourable behaviour with the welfare dependency that their hard earned taxes are funding:

"Most people in this country don't wake up early in the dark and cold, and head to their job in order for the state to take their money and waste it. They don't slump, exhausted in their chair after work, just to see their taxes spent on people who can work but won't... How easy it would be for them [workers] to give up and fall back on the state, like too many they see around them" (Duncan Smith, 2010). 
In Duncan Smith's speech, dichotomous divisions between work and non-work are employed instrumentally to justify the need for welfare reform to challenge passive welfare dependency and instil the responsibility to work. Admittedly, the Government accepts that there remains a residual category of the most vulnerable and deserving benefit claimants who are judged to be entitled to state support without fulfilling any reciprocal work-related duties. However, the boundaries between those benefit claimants who are expected to work and those judged exempt as a result of their particular needs or competing responsibilities, have been reshaped such that the great majority are now subsumed within the rhetorical category of 'irresponsible' welfare dependents.

Over the past 12 months, alongside the sustained recourse to good worker - bad benefit claimant dualisms, we have witnessed the birth of new discursive categories to describe and even romanticise the activities of responsible citizens workers whom lain Duncan Smith (ibid.) categorises as 'the true beating heart of the nation'. Ed Miliband (2011b) is determined to make his Labour party 'once again the party of the grafters' and has set out to defend the rights of the 'squeezed middle': those behaving as they should but still struggling in a Britain that does not adequately reward hard work. Not wanting to be outdone, Nick Clegg promised help to members of 'alarm clock Britain'. These discursive categories serve to reinforce and capitalise on divisions between a welfare claiming class and the working majority.

In utilising binary oppositions and continuously stereotyping and undermining the behaviour of benefit claimants, the Coalition government is arguably exploiting what Young (2002) describes as 'relative deprivation downwards' to suit its own ends. Drawing on the work of Runciman (1966) and others, Young (2002) argues that people can experience a feeling of unfairness towards those lower down the income scale where a belief emerges that "those who work little or not at all are getting an easy ride on your back and your taxes" (p. 480). In tough economic contexts, feelings of relative deprivation downwards can escalate and develop into vindictiveness where people want to see harm done to the prospects of those worse off than themselves (ibid.). Grover (2010) has applied Young's arguments to contemporary social security policy, which he describes as characterised by a 'politics of vindictiveness' with measures aimed at changing the behaviour of benefit claimants and a frequent recourse to punitive policy tools. This assessment has real relevance to today's Britain, where a challenging economic and social context is leading to widespread feelings of relative deprivation downwards which are being capitalised on by a government content to engage in just such a politics of vindictiveness. Indeed, Cameron (2011b) arguably drew on and explicitly exploited feelings of relative deprivation downwards in a speech to launch the 2011 Welfare Reform Bill:

"I've had young people in my constituency surgery who come in and say: 'I'm doing the right thing, saving up for a home with my boyfriend, making sure we're secure before we have kids but the girl down the road has done none of the above and yet having a baby has got her a flat and benefits that I'm doing without'... Should we be content with a system that it seen by some as saying: have a baby now, get a home and some cash; wait until later, when you're more secure and stable, and you may get neither?"

By exalting the behaviours of those who work and subtly demeaning those who do not, the Coalition attempts to justify swingeing benefit cuts and tough sanctions for those not performing the responsible worker role. The moralising implicit in this agenda rests upon a continued emphasis on the promotion of paid work, and sketches out a clear role for governments in promoting working behaviours and undermining, if not explicitly punishing, non-work. Critically, though, moral censure for non-work seems 


\section{p. 11. Work as the primary 'duty' of the responsible citizen: a critique of this work-centric approach}

only to extend to those who are out of work and reliant on the state for support, with those who are able to escape the obligation to work, whether due to the presence of a wealthy partner or unearned wealth, similarly seeming to escape from being an object of the Government's condemnation.

\section{Critiquing the work-centric approach: the 'problem of riches'?}

Throughout this paper, tensions and shortcomings with the Government's depiction of work as the primary duty of the responsible citizen have been highlighted, with the issue of whether work is transformative in every instance already considered. Similarly, there are also real issues with a citizenship discourse that focuses so squarely on paid work, given how far it simultaneously neglects and devalues other forms of social contribution such as parenting, care work, volunteering and engaging in service user activities. Disabled people, for example, may be over-represented in the out-of-work statistics but are often active as volunteers or service users helping improve service standards for themselves and their peers (Office for Disability Issues, 2012). By continually articulating the value and importance of formal paid work, while showing much less appreciation of these activities, politicians risk further excluding those who may already have a precarious citizenship status. Evidently, a citizenship approach which gives paid work such central import serves to reinforce the exclusionary potential of citizenship with those not working effectively becoming second-class citizens.

The valorisation of work and the dichotomies between responsible workers and irresponsible benefit claimants, between independence and dependence, are grounded in a false and unsustainable reading of dependency. Over sixty years ago, Titmuss (1963) reminded us that we are all welfare dependents by looking beyond social welfare to reliance on occupational and fiscal welfare provision (Sinfield, 1978). $\mathrm{He}$ argued that criticisms of the welfare state are of little relevance whilst they “...remain attached to a stereotype of social welfare which represents only the most visible part of the real world of welfare" (1963: 53). His thesis has enduring relevance today in a political climate that narrowly equates welfare dependency with out-of-work benefits, seeming to deliberately ignore created dependencies arising from tax credits, child care support, pension relief and occupational benefits. Politicians also adopt a uni-dimensional notion of welfare dependency that fails to consider movement and transition across the life course as people's dependencies and work patterns change over time.

Inevitably, a discourse that casts employment in direct opposition to out-of-work benefits leads to a simplistic and unsustainable conception of social justice. Importantly, work versus non-work is not necessarily either the only, or even the most significant, dichotomy when looking to questions of desert, justice and both the rights and responsibilities of citizenship. Operating a working - good; not- working - bad binary neglects inequalities and differences among citizens that can arise regardless of whether they are engaging in paid work. Thus, for example, the continued elevation of paid work ignores issues of low wages and unjust returns for paid work, as well as challenging questions regarding whether all paid work is by default 'good'. This latter issue is particularly pertinent given the recent actions of the bankers whose 'hard' work precipitated global recession (Lanchester, 2010; Tett, 2010).

In a climate of financial austerity, there is renewed interest amongst academics (Dorling, 2011; Hutton, 2011; Wilkinson and Pickett, 2010), the public and the media in the appropriate financial rewards provided by benefits and paid work across the spectrum, as well as the extent and consequences of economic inequality. Simplistically valorising paid work and demeaning reliance on out-of-work benefits only 
operates as one - arguably crude and pernicious - defence for the inequality between those in and outside of the paid labour market. It fails to deal with a range of equally important matters such as inequalities within the workplace and questions regarding how, and whether, socially valuable 'work' such as parenting, caring and volunteering should be rewarded. A repeated celebration of the activities of the hard-working majority, as juxtaposed with the attitudes and behaviours of the deserving and - most often - undeserving poor is also undermined by the increased interest in the media and public discourse regarding the salaries and activities of some of our wealthiest 'employees'. The growing awareness that undeservingness and irresponsibility are not the sole preserve of those at the bottom of the income spectrum is a potent challenge to the contemporary political conceptualisation of paid work.

Unfortunately, though, the Government's emphasis on benefit claimants' responsibility to enter work is not accompanied by a systematic consideration of the responsibilities of those at the top end of the income scale, who are often allowed to largely escape the moralising agenda of the Government by virtue of their independent means. Admittedly, under Ed Miliband's leadership there are some signs that the Labour Party wants to simultaneously interrogate the behaviours of both the irresponsible rich and the irresponsible poor (cf. Miliband, 2011b; 2011a; 2011c). Talking after the riots, Miliband (2011c) argued: "Let's not pretend that the crisis of values in our society is confined to a minority only at the bottom when we see the morality of millions of hardworking, decent people under siege from the top as well". However, this analysis is again based on an over-simplistic reading, with the hardworking - and tax paying - majority praised, while the behaviours of individuals sitting at society's polar extremes of wealth and poverty are subject to interrogation and ultimately moral censure.

While both Miliband and now Cameron are showing some interest in efforts to reign in irresponsible capitalism, it is unclear whether there is much policy substance behind this rhetoric - action to contain bonuses and remove Fred Goodwin's knighthood notwithstanding. Indeed, a clear distinction can be made between the impacts of political moralising experienced by those at opposing ends of the income spectrum. The moral questioning of the behaviours and dependencies of the poorest is accompanied by harsh policy measures to try and alter their behaviour, which include sanctions, reductions in benefits and ever increasing work-related conditionality. By contrast, it appears that the current turn towards interrogating elements of the business practices and rewards received by the richest in society is largely political posturing and - as yet - shows little signs of being accompanied by meaningful policy reform. However, as the consequences of government action to reduce the deficit continue to be felt across Britain, it may be that it becomes politically unsustainable to critique business bonuses and levels of top-end remuneration without accompanying this sentiment with legislative changes and systematic challenges to the status quo.

\section{Where 'big society' and work collides}

While the government sees work having the potential to strengthen family life and civil society by instilling a broader sense of moral and civic duty, there are enduring tensions between engagement in paid work and the activities of parenting and participation in Cameron's much discussed but little understood Big Society. The very act of encouraging lone parents back to work implies that parenting does not constitute work (Fraser and Gordon, 1994), while also underplaying questions regarding how far participation in the formal labour market is always compatible with responsible and engaged parenting. Post-riots, government ministers were quick to condemn the activities of the 'irresponsible' parents of rioters and have since threatened to withdraw 


\section{p. 13. Work as the primary 'duty' of the responsible citizen: a critique of this work-centric approach}

benefits from those whose children repeatedly truant from school (Cameron, 2011a). However, this policy rhetoric and punitive prescription overlooks the reality that parents may be attempting to juggle work and parenting and that this juggling may in itself make supervisory, active parenting much more difficult. With regard to Cameron's big 'passion' - a Big Society - engagement in civil society by volunteering requires the luxuries of time and resources, resources that may be in short supply if working long hours for low pay. Furthermore, while the Big Society rhetoric seeks to recognise and celebrate civil society and volunteering, this is rather undermined by the Government's simultaneous and more insistent emphasis on work as the most fundamental of citizenship duties.

The Government's analysis, shared by New Labour, is based on a narrow definition of work as formal paid employment. A more emancipatory and inclusive citizenship model would broaden 'work' to encompass caring, voluntary work and other forms of socially valuable contribution. While political discourses discount and undermine dependency, feminist ethic of care theorists remind us that we are all dependent in some way, and that dependency is a normal - even a valuable - human quality (Mink, 1998; Kittay, 1999). Were the reality of human interdependence to be acknowledged, as well as efforts to redefine our understanding of work taken seriously, the dualisms and dichotomies between workers and non-workers - the responsible and irresponsible - would be far less potent and might collapse entirely. Given the Government's welfare reform agenda, it is unsurprising that they choose to tie their policy rhetoric and defences to these simplistic binary distinctions and engage in a continued valorisation of work in the formal labour market. It then becomes the responsibility of those outside mainstream politics and in academia to challenge these discourses and demonstrate the unsustainable premises on which they are based.

\section{Conclusion}

This paper has explored the continued promotion of paid work as the primary duty of the responsible citizen. The many shortcomings of contrasting a simplistic valorisation of paid work with the 'problem' of 'dependency' suggests that one of the central premises of both welfare-to-work policy and the broader welfare reform agenda is open to challenge. Rather than continually promoting all paid work, the Government would be wise to instead concentrate their policy energies and reforming strategies on considerations of how best to improve the quality of work available, alongside action to reduce the extent of inequalities within the working population. At the same time, the Government should also consider what messages are sent out by its implicit undermining of the many forms of unpaid work in which so many are engaged.

Importantly, an increased awareness of the sometimes irresponsible behaviours of the richest may serve to destabilise neat separations between the supposedly undeserving unemployed, and the deserving 'hard working majority'. While academics have long critiqued a work-centric citizenship approach (cf. Dwyer, 2010; Lister, 2003), there is great potential in analysing the ways in which the behaviours of some of the richest are now becoming subject to political discussion. Future questions to consider might include similarities and differences between the interrogation of the richest and poorest in our society, as well as which social policy interventions might operate to encourage - and even compel - those segments of the richest in our society judged to be acting irresponsibly to alter their behaviour so as to become both more responsible and more' deserving' of the various 'bailouts' and welfare they receive.

* Correspondence address: Ruth Patrick, School of Sociology and Social Policy, University of Leeds, Leeds, LS2 9JT. Email: r.patrick@leeds.ac.uk. 
p. 14. Work as the primary 'duty' of the responsible citizen: a critique of this work-centric approach

\section{References}

Cameron, D. (2011a) PM's speech on the fightback after the riots [online]. [Accessed 16/08/11]. Available from: http://www.number10.gov.uk/news/pms-speech-onthe-fightback-after-the-riots/.

Cameron, D. (2011b) PM's speech on Welfare Reform Bill, 17 February [online]. [Accessed 21/2/11]. Available from: http://www.number10.gov.uk/news/speeches-and-transcripts/2011/02/pmsspeech-on-welfare-reform-bill-60717.

Conservatives (2010) A New Welfare Contract. London: The Conservatives.

Crisp, R., Batty, E., Cole, I. and Robinson, D. (2009) Work and worklessness in deprived neighbourhoods: Policy assumptions and personal experiences. York: Joseph Rowntree Foundation.

Deacon, A. (2002) Perspectives on welfare: ideas, ideologies, and policy debates. Maidenhead: Open University Press.

Deacon, A. and Patrick, R. (2011) A new welfare settlement? The Coalition government and welfare-to-work, in: H. Bochel, ed. The Conservative Party and Social Policy. Bristol: The Policy Press, pp. 161-179.

Dean, H. (1999) Citizenship, In: M. Powell, ed. New Labour, New Welfare State? The 'third way' in British social policy. Bristol: The Policy Press, pp. 213-233.

Department for Social Security (1998) New ambitions for our country: A new contract for welfare, Green Paper, Cmnd 3805. London: The Stationery Office.

Department for Work and Pensions (2008) Raising expectations and increasing support: reforming welfare for the future, Cmnd. 7506. London: Department for Work and Pensions.

Department for Work and Pensions (2010) Universal Credit: welfare that works, Cm 7957. London: The Stationery Office.

Dorling, D. (2011) Injustice: Why social inequality persists. Bristol: The Policy Press.

Duncan Smith, I. (2010) Our contract with the country for 21st Century Welfare, Speech to Conservative Party Conference, 5th October [online]. [Accessed 7/10/10]. Available from: http://www.conservatives.com/News/Speeches/2010/10/lain Duncan Smith 0 ur_contract_with the country for_21st_Century_Welfare.aspx.

Dwyer, P. (2010) Understanding Social Citizenship, themes and perspectives for policy and practice, Second Edition. Second ed. Bristol: The Policy Press.

Fraser, N. and Gordon, L. (1994) 'Dependency' Demystified: Inscriptions of Power in a Keyword of the Welfare State. Social Politics 1, 1, 4-31.

Gilbert, N. and Besharov, D. (2011) Welfare states amid economic turmoil: adjusting work-orientated policy. Policy and Politics, 39, 3, 295-308.

Grover, C. (2010) Social Security Policy \& Vindictiveness. Sociological Research Online, 15, 2.

Hutton, W. (2011) Them And Us: Changing Britain - Why We Need a Fair Society. London: Abacus.

Kittay, E. F. (1999) Welfare, Dependency and a Public Ethic of Care, In: G. MINK, ed. Whose Welfare? . Ithaca: NY Cornell University Press pp. 189-213.

Lanchester, J. (2010) Whoops!: Why everyone owes everyone and no one can pay. London: Penguin Books.

Levitas, R. (2005) The Inclusive Society? Social Exclusion and New Labour, Second Edition. London: Macmillan Press.

Lister, R. (2001) 'Work for those who can, security for those who cannot.' A third way in social security reform or fractured social citizenship? In: R. Edwards and J. Glover, eds. Risk and citizenship - key issues in welfare. London: Routledge, pp. 96-109.

Lister, R. (2003) Citizenship: feminist perspectives, Second Edition. Basingstoke: Palgrave. 
Marshall, T. H. (1949) Citizenship and social class, In: T. H. Marshall and T. Bottomore, eds. Citizenship and social class. London: Pluto Press, pp. 3-51.

Miliband, E. (2011a) Cameron now hamstrung by his own decisions over Coulson [online]. [Accessed 26/07/11]. Available from: http://www.labour.org.uk/edmiliband-cameron-hamstrung-over-coulson.

Miliband, E. (2011b) Ed Miliband's speech to Labour Party Conference [online]. [Accessed 28/09/11]. Available from: http://www.labour.org.uk/ed-milibandsspeech-to-labour-party-conference.

Miliband, E. (2011d) Responsibility in 21st Century Britain, Speech at Coin Street Neighbourhood Centre, 13th June [online]. [Accessed 15/06/11]. Available from: http://www.labour.org.uk/ed-miliband-speech-responsibility,2011-06-13.

Mink, G. (1998) Welfare's End, Revised Edition. Ithaca: NY Cornell University Press.

Newman, I. (2011) Work as a route out of poverty: a critical evaluation of the UK welfare to work policy. Policy Studies, 32, 2, 91-108.

Office for Disability Issues (2012) Disability facts and figures [online]. [Accessed 12/02/12]. Available from: http://odi.dwp.gov.uk/disability-statistics-andresearch/disability-facts-and-figures.php.

Overell, S. (2011) Jobs are not enough: it's the quality of work that counts [online]. [Accessed 22/03/11]. Available from: http://www.guardian.co.uk/commentisfree/2011/mar/17/jobs-work-coalitionquality-of-life.

Piven, F. F. (1972) Regulating the poor: the functions of public welfare. London: Tavistock Publications.

Prideaux, S. (2005) Not so New Labour: a sociological critique of New Labour's policy and practice. Bristol: The Policy Press.

Runciman, W. G. (1966) Relative Deprivation and Social Justice: A Study of Attitudes to Social Inequality in Twentieth-Century England. London: Routledge \& Kegan Paul.

Sinfield, A. (1978) Analyses in the Social Division of Welfare. Journal of Social Policy, 7 , 2, 129-156.

Tett, G. 2010. Fool's Gold: How Unrestrained Greed Corrupted a Dream, Shattered Global Markets and Unleashed a Catastrophe. London Abacus.

Titmuss, R. M. (1963) Essays on 'the welfare state'. Second ed. London: George Allen and Unwin.

Toynbee, P. (2011) You can't cut $£ 18 b n$ from the poorest without pain. The Guardian $p$. 34.

Wadell, G. and Burton, A. K. (2006) Is work good for your health and well-being, An independent review commissioned by the Department for Work and Pensions. London: The Stationery Office.

Walters, W. (1997) The 'active society': new designs for social policy. Policy and Politics, $25,3,221-233$.

Warren, J. (2005) Disabled people, the state ad employment: historical lessons and welfare policy, In: A. Roulstone and C. Barnes, eds. Working Futures? Disabled people, policy and social inclusion. Bristol: The Policy Press, pp. 301-313.

Wilkinson, R. and Pickett, K. (2010) The Spirit Level: Why Equality is Better for Everyone. London: Penguin.

Wright, S. (2009) Welfare to Work, In: J. MILLAR, ed. Understanding Social Security, Issues for policy and practice, Second Edition. Bristol: The Policy Press, pp. 193212.

Young, J. (2002) Crime and Social Exclusion, In: M. Maguire, R. Morgan and R. Reiner, eds. The Oxford Handbook of Criminology, Third Edition. Oxford: Oxford University Press, pp. 457-490. 